\title{
KOMPLEKSITAS KEPEMIMPINAN PEREMPUAN DI AUSTRALIA
}

\author{
Utari Diyarza Utami \\ Fakultas Ilmu Sosial dan Ilmu Politik, Ilmu Hubungan Internasional \\ Universitas Islam Negeri Syarif Hidayatullah Jakarta \\ Email: utari.diyarza17@mhs.uinjkt.ac.id
}

\begin{abstract}
ABSTRAK
Penulisan ini bertujuan untuk mengetahui apa saja tantangan kepemimpinan perempuan di dunia internasional dan Australia pada khususnya. Dalam menganalisa lebih dalam terkait kompleksitas kepemimpinan perempuan di Australia, penulis menggunakan teori feminisme. Penulis membahas faktor-faktor penyebab adanya diskriminasi yang didapatkan perempuan selama mereka menjabat di beberapa posisi penting pemerintahan, termasuk membahas kepemimpinan Julia Gillard yang pernah menjabat sebagai Perdana Menteri Australia, serta tantangan yang Gillard hadapi terkait diskriminasi gender. Sebagai kesimpulan bahwa kepemimpinan perempuan di dunia internasional dan khususnya Australia masih mengalami diskriminasi dari masyarakat lokal maupun yang berasal dari dunia internasional itu sendiri.
\end{abstract}

Kata Kunci: Tantangan kepemimpinan perempuan, Gender, Feminisme, Australia, Diskriminasi, Julia Gillard

\begin{abstract}
This paper aims to find out what are the challenges of women's leadership in the international world and Australia in particular. In analyzing more deeply the complexity of women's leadership in Australia, the author uses the theory of feminism. The author discusses the factors that cause discrimination experienced by women during their tenure in several important government positions, including discussing the leadership of Julia Gillard, who had served as Prime Minister of Australia, as well as the challenges that Gillard faced related to gender discrimination. As a conclusion, the leadership of women in the international world and especially Australia still experiences discrimination from local communities and those from the international world itself.
\end{abstract}

Keywords: Women's leadership challenges, Gender, Feminism, Australia, Discrimination, Julia Gillard

\section{PENDAHULUAN}

Ilmu Hubungan Internasional bukan hanya mengenal gender laki-laki tetapi juga perempuan sebagai gender yang berperan penting. Peran perempuan dalam penyelesaian konflik yang bertujuan menegakkan perdamaian adalah suatu nilai lebih yang dimiliki perempuan dalam dunia internasional. Dewasa ini, perempuan tidak lagi menjadi aktor yang dikesampingkan dalam mengambil sebuah keputusan, walaupun jika dilihat faktanya 
adalah masih banyak posisi-posisi yang belum dapat disentuh oleh perempuan. Pada tulisan kali ini kita berfokus kepada Australia yang menjadi contoh kasus kepemimpinan perempuan beserta tantangan-tantangannya.

Di Australia dapat kita lihat bahwa perempuan memiliki jumlah yang jauh lebih signifikan memegang peranan sebagai aktor di semua level layanan publik. Namun sangat disayangkan, aktor-aktor perempuan ini belum dapat mengisi berbagai posisi yang lebih dianggap penting seperti pada kepemimpinan di berbagai lembaga tinggi Australia terutama pada bidang diplomasi dan keamanan(Elise Stephenson, 2019). Kepemimpinan seorang perempuan memang masih menimbulkan banyak perdebatan tak terkecuali di Australia. Perdebatan tentang kepemimpinan seorang perempuan sebenarnya timbul dari berbagai faktor salah satunya ialah kurangnya penelitian yang melaporkan data empiris hasil dari kepemimpinan seorang perempuan bukan hanya di Australia tetapi juga di dunia internasional (Danspeckgruber, 2010).

Sangat disayangkan apabila di dunia internasional masih sangat jarang penelitian yang memberikan penjelasan terkait kepemimpinan seorang perempuan dan bagaimana $\mathrm{HI}$ melihatnya. Penelitian yang dilakukan hendaknya dapat memberikan informasi seperti kelebihan dan kekurangan kepemimpinan yang diketuai oleh perempuan sehingga dapat disimpulkan apa-apa saja hambatan yang dihadapi oleh pemimpin-pemimpin perempuan di seluruh dunia khususnya di Australia. Menurut penulis, hambatan yang paling utama adalah berasal dari anggapan bahwa perempuan adalah gender kedua, sehingga memberikan konstruk bahwa perempuan selalu dinomor duakan dalam berbagai aspek terutama untuk menjadi seorang pemimpin.

Di dalam jurnal Australian Journal of International Affairs disebutkan setidaktidaknya terdapat 4 faktor penjelas terkait kepemimpinan perempuan yaitu: tingkat senioritas perempuan, status keterwakilan perempuan, norma diplomatik dan apa pengalaman perempuan di rumah dan di urusan luar negeri mereka(Elise Stephenson, 2019). Empat faktor diatas dapat menjadi sebuah pisau analisis kita terhadap apa saja yang akan menjadi hambatan seorang perempuan jika menjadi seorang pemimpin. Namun yang masih menjadi faktor utama dan terpenting terkait kepemimpinan seorang perempuan adalah munculnya diskriminasi terhadap hampir semua pemimpin perempuan bahkan hingga mengalami pelecehan dan diskriminasi seksual yang datang dari laki-laki Australia(Schultz, 2014). 
Walaupun Australia sempat memberikan pernyataan untuk sepenuhnya mendukung kepemimpinan perempuan. tetapi respon masyarakat terhadap pemimpin perempuan di Australia dianggap tidak linear dengan pernyataan dari pihak pemerintah Australia. Walaupun di Australia perempuan dinilai lebih aktif di pemerintahan karena adanya keterbukaan dan kebebasan jika dibandingkan dengan negara-negara lain, tetapi perempuan tidak mendapatkan kepercayaan masyarakat sepenuhnya jika mengajukan diri menjadi seorang pemimpin, masih banyak timbul keraguan saat perempuan muncul sebagai pemimpin yang menyamai laki-laki (Adeed, 2018).

Di dunia internasional pun yang notabene nya mendukung penuh kepemimpinan dan kesetaraan gender, masih mendapatkan berbagai tantangan jika dihadapkan dengan masalah yang terkait dengan gender dan etnis. Bukti nyata dan kurangnya penelitian terhadap kepemimpinan perempuan juga menjadi salah satu faktor penting dalam memberikan pemahaman dan kepercayaan masyarakat kepada pemimpin perempuan.

\section{KERANGKA TEORI}

\section{FEMINISME}

Feminisme adalah sebuah teori yang termasuk kedalam postpositivisme, dimana teori ini membahas tentang gender. Menurut kamus besar Bahasa Indonesia, feminisme dapat diartikan sebagai gerakan perempuan yang menuntu persamaan hak antara perempuan dan laki-laki (No Title, 2018). Feminisme hadir untuk mempertanyakan dan mengkritik mengapa didalam Hubungan Internasional hanya menceritakan tentang lakilaki dan kehidupannya serta mengenyampingkan perempuan (Burchill, n.d.). Dominasi kaum pria di dalam Hubungan Internasional lah yang akhirnya menjadi alasan utama lahirnya feminisme. menurut feminisme, didalam Hubungan Internasional terdapat bias gender yang akhirnya mendiskriminasi salah satu gender yaitu feminim. Seperti yang dikatakan oleh Cynthia Enloe, sebenarnya perempuan itu sudah dan selalu ada di dalam Hubungan Internasional, namun dikarenakan hanya sejarah dari laki-laki terkait perang dan konflik yang selalu menjadi pembahasan penting di Hubungan Internasional membuat maskulinitas didalam HI sangat mendominasi(Enloe, 2014). Feminisme biasanya membahas tentang pola relasi yang terjadi di masyarakat memandang posisi perempuan dan laki-laki dalam mendapatkan status, kedudukan dan hak nya baik di sektor public maupun domestik(Ii \& Feminisme, n.d.). 
Untuk mengetahui feminisme lebih dalam, mari kita lihat perspektif yang dibawa oleh Jacqui True yang membagi feminisme ini menjadi tiga bagian yaitu feminisme analitis, feminisme empiris dan feminisme normatif (Burchill, n.d.). Menurut feminisme analitis, dunia pada saat sebelum lahirnya feminisme didominasi oleh maskulinitas yang membahas isu-isu high politics, feminisme jenis ini juga ingin memberi pemahaman baru dalam kerangka teoritis Hubungan Internasional dengan cara mengungkapkan adanya penyimpangan pemikiran antar gender yang kelak dipercayai akan menghambat pemahaman yang akurat dalam Hubungan Internasional. Jenis kedua yaitu feminisme empiris. Feminisme jenis ini membahas isu tentang eksploitasi perempuan sebagai akibat dari sistem ekonomi global. Jenis yang ketiga yaitu feminisme normatif. Feminisme jenis ini bertujuan untuk merefleksikan teori hubungan internasional sebagai agenda normatif perubahan global (Burchill, n.d.).

Selain itu, feminisme juga memiliki berbagai aliran diantaranya adalah feminisme liberal, feminisme radikal, feminisme marxis dan feminisme sosialis. Aliran pertama yaitu feminisme liberal, feminisme aliran ini berfokus pada persamaan hak antara perempuan dan laki-laki, feminisme aliran ini ingin menghapuskan segala bentuk diskriminasi yang ditujukan pada kaum perempuan(Ii \& Feminisme, n.d.). Aliran selanjutnya yaitu feminisme radikal, feminisme aliran ini berfokus pada perbedaan biologis dan psikologis antara kaum perempuan dan laki-laki sehingga feminisme dengan aliran ini menganggap bahwa penyebab dominasi yang dilakukan kaum laki-laki terhadap perempuan ialah berasal dari kapasitas reproduktif yang perempuan miliki. Aliran ketiga yaitu feminisme marxis, feminisme dengan aliran marxis yang dilandaskan oleh pemikiran Karl Marx biasanya berfokus pada ketimpangan yang terjadi pada upah buruh perempuan dan lakilaki. Aliran feminisme yang terakhir akan dibahas pada tulisan ini yaitu feminisme dengan aliran sosialis, feminisme aliran ini berfokus pada bagaimana konstruk sosial menjadi sumber ketimpangan yang terjadi antar perempuan dan laki-laki.

Feminisme menjadi sebuah teori yang paling sesuai dalam menjelaskan kompleksitas kepemimpinan perempuan yang terjadi di Australia. Di Australia sendiri kepemimpinan seorang perempuan masih menimbulkan pro dan kontra. Di dunia internasional, kepemimpinan seorang perempuan dianggap sebagai sebuah kemajuan bagi hubungan internasional tetapi kondisi yang sangat berbeda saat dibandingkan dengan respon masyarakat lokal Australia terkait adanya kepemimpinan yang dipimpin oleh seorang perempuan. Banyak tantangan-tantangan yang dihadapi pemimpin-pemimpin 
perempuan Australia justru berasal dari masyarakat lokal Australia itu sendiri. Pemimpin perempuan seakan-akan diragukan keprofesionalitasannya dan selalu dibandingbandingkan dengan pemimpin yang berasal dari gender laki-laki.

\section{KAJIAN LITERATUR}

Untuk mengetahui lebih dalam terkait bahasan pada paper ini, penulis sudah melakukan studi pustaka terhadap beberapa referensi yang terkait dengan bahasan yang ada pada paper ini. Studi pustaka yang pertama yaitu berasal dari jurnal yang ditulis oleh Ezzah Nuranisa yang berjudul Kerjasama "Kemitraan Indonesia-Australia untuk Kesetaraan Gender dan Pemberdayaan Perempuan” (Mampu) Dalam Mengatasi Permasalahan Perempuan Pekerja Rumahan di Daerah Istimewa Yogyakarta (Nuranisa \& Saepudin, 2019). Jurnal yang ditulis Ezzah ini membahas tentang bagaimana kondisi Perempuan Pekerja Rumahan (PPR) di Daerah Istimewa Yogyakarta (DIY) yang belum sepenuhnya mendapatkan perlindungan dan hak nya sebagai pekerja. Tulisan ini juga membahas program yang digagas oleh Indonesia dan Australia dalam mengupayakan penegakkan keadilan untuk Perempuan Pekerja Rumahan yang ada di Yogyakarta. Kemitraan Indonesia-Australia melalui program MAMPU hendak berupaya memajukan dan memberdayakan Perempuan Pekerja Rumahan menjadi pekerjaan yang layak.

Persamaan yang terdapat dari tulisan Ezzah dan tulisan ini yaitu terletak pada pembahasan gender di Australia sebagai salah satu contoh untuk pemberdayaan Perempuan Pekerja Rumahan di Yogyakarta. Adapun perbedaannya yaitu terletak pada fokus yang diambil oleh masing-masing penulis, penulis pada tulisan kali ini memfokuskan bahasan tentang kompleksitas dan tantangan pemimpin perempuan di Australia sedangkan tulisan Ezzah lebih berfokus pada tujuan pemberdayaan Perempuan Pekerja Rumahan agar menjadi pekerjaan yang layak bagi perempuan-perempuan Yogyakarta.

Tinjauan pustaka selanjutnya berasal dari tulisan yang dimuat di ABC Australia yang diterbitkan DetikNews dengan judul "Perempuan Lintas Agama Indonesia Belajar Kepemimpinan di Australia". Tulisan ini menjelaskan bagaimana kegiatan yang diikuti oleh 27 tokoh lintas agama yang berasal dari Indonesia mengikuti program kursus singkat Leadership for Senior Multi-Faith Women Leaders 2018. Kegiatan ini memberikan informasi terkait pengelolaan organisasi-organisasi yang dilakukan perempuan-perempuan Australia. Tulisan ini juga menyebutkan pendapat dari salah satu peserta yang ikut serta dalam kegiatan Leadership for Senior Multi-Faith Women ini. dijelaskan pula bahwa 
kegiatan ini membangun semangat keberagamaan untuk memperkuat kebersamaan antar perempuan umat beragama.

Persamaan tulisan ini dengan berita yang dimuat DetikNews adalah tentang bagaimana memperlihatkan bahwa perempuan-perempuan Australia sudah memiliki tingkat kesadaran yang lebih tinggi terkait pembahasan kesetaraan antar perempuan dan laki-laki. Telah banyak organisasi-organisasi di Australia yang pemimpinnya adalah seorang perempuan sehingga menunjukkan bahwa perempuan dapat menjadi pemimpin yang baik tanpa harus dibanding-bandingkan dengan kaum laki-laki. Perbedaannya terletak pada fokus yang berbeda antara tulisan ini dengan tulisan yang dimuat oleh DetikNews. Tulisan yang dimuat oleh DetikNews hanya menyebutkan pemimpin-pemimpin perempuan Australia yang berhasil mengelola organisasi-organisasi besar sehingga 27 tokoh perempuan yang berasal dari Indonesia mengikuti program pelatihan yang diadakan di Deakin University Melbourne. Sedangkan tulisan ini lebih berfokus pada bagaimana kepemimpinan seorang perempuan direspon oleh dunia internasional khususnya masyarakat lokal Australia, tulisan ini juga membahas apa saja tantangan dan kemudahan yang dialami oleh pemimpinpemimpin perempuan di dunia internasional maupun di level domestic Australia itu sendiri. Tulisan ini membahas lebih dalam dan hanya berfokus pada pro dan contra yang ditujukan terhadap kepemimpinan seorang perempuan di Australia (Australia-DetikNews, 2018).

Tinjauan pustaka yang terakhir yaitu berasal dari sebuah jurnal yang ditulis oleh R.Aj Rizka Fiani Prabaningtyas dengan judul "The Impact of Australian Policy on Illegal Maritime Arrivals (IMA) Towards Current Relation of Australia-Indonesia" (R.Aj Rizka Fiani Prabaningtyas, 2015). Tulisan ini banyak membahas tentang permasalahan pencari suaka yang datang ke wilayah Australia, tulisan ini juga menjelaskan masa kepemimpinan Julia Gillard saat dia menjabat menjadi seorang Perdana Menteri Australia. Tulisan ini menjelaskan apa saja kebijakan-kebijakan yang Julia Gillard ambil dalam merespon isu IMA ini dan bagaimana akhir dari kepemimpinan Gillard.

Persamaan tulisan yang ditulis oleh R.Aj Rizka Fiani Prabaningtyas dengan tulisan ini ialah sama-sama membahas masa kepemimpinan Julia Gillard sebagai seorang Perdana Menteri. Namun yang membedakan tulisan ini dengan tulisan Rizka ialah tulisan ini akan lebih jauh membahas faktor-faktor yang timbul dari pribadi Julia Gillard terhadap penilaian masyarakat Australia terhadap kepemimpinan seorang perempuan. 


\section{PEMBAHASAN}

Seperti yang kita ketahui bahwa di dalam dunia internasional, perempuan telah mengambil banyak peran yang berarti seperti pembentukan hukum dan penentuan kebijakan, melakukan diplomasi untuk penyelesaian perang, berperan aktif dalam aksi-aksi perdamaian dan masih banyak lagi. Namun yang perlu kita garis bawahi bahwa dinamika keterlibatan perempuan disetiap negara memiliki tingkat keaktifan yang berbeda, misalnya kita lihat di negara Australia

Memang betul bahwa total jumlah perempuan yang berkontribusi di bidang layanan publik hingga ke tingkat eksekutif lebih banyak daripada jumlah laki-laki. Namun yang sangat amat disayangkan jika kita melihat cakupan yang lebih luas dan besar contohnya pada bidang keamanan dan diplomasi, suara-suara perempuan kurang terwakilkan. Sebenarnya dalam sejarah diplomatik, memang sudah banyak yang menyebutkan bahwa peran perempuan sangat dibatasi karena memperhatikan banyak faktor pengikat yang ada pada diri perempuan sehingga menjadi pertimbangan yang sangat matang melihat konsekuensi yang akan diterima apabila perempuan tetap dilibatkan pada kepemimpinan di dunia internasional.

Namun dewasa ini, tingkat keterlibatan perempuan diberbagai posisi penting dalam pemerintahan Australia memperlihatkan angka yang cukup signifikan, ini berarti kepemimpinan perempuan di Australia sudah mengalami peningkatan yang sangat baik jika dibandingkan dengan tahun-tahun sebelumnya. Fakta ini dapat kita lihat bahwa sudah lebih banyak perempuan yang terlibat di Australia Public Service (APS) dan sudah cukup banyak pula perempuan yang mengisi posisi-posisi tinggi di APS ini. Bukan hanya itu saja, Australia dengan mengejutkan menunjuk 2 Menteri perempuan secara bersamaan yaitu Menteri Luar Negeri dan Menteri Pertahanan, Sekretaris Kementerian Luar Negeri Australia juga disandang oleh seorang perempuan.

Jika kita melihat hal ini tentulah menjadi sebuah kemajuan yang sangat baik yang telah dicapai Australia dalam mengatasi diskriminasi gender. Australia adalah salah satu negara yang memiliki undang-undang anti diskriminasi terhadap gender. Namun disisi lain dari meningkatnya kepemimpinan di Australia terdapat fakta yang lain yaitu kepemimpinan perempuan di Australia masih dianggap lebih buruk jika dibandingkan dengan kepemimpinan seorang laki-laki. Bahkan disebutkan pula bahwa di dunia internasional kepemimpinan seorang perempuan secara general ditempatkan dibawah posisi laki-laki (Towns, A., 2017). 
Sebenarnya sudah ada beberapa contoh kepemimpinan yang berhasil di Australia sendiri, namun masih sering diabaikan. Di Australia, kepemimpinan perempuan di dunia internasional masih menjadi pembahasan yang menarik dan isu yang hangat untuk diperdebatkan di dalam negeri maupun internasional (Conley Tyler, M., E. Blizzard, 2014). Yang sering sekali dikaitkan dengan kepemimpinan dari seorang perempuan ialah tentang tugas dan tanggung jawab seorang perempuan pada keluarganya sehingga ini dilihat sebagai salah satu hambatan mengapa pemimpin perempuan mengalami banyak tantangan dan hambatan. Banyak pihak yang mengeneralisir beban ganda yang diemban perempuan meliputi pekerjaan di dalam dan luar rumah juga akan terjadi apabila seorang perempuan ini menjadi seorang pemimpin apalagi mewakili sebuah negara. Perempuan masih dianggap belum dapat secara professional memisahkan ruang pribadi dan ruang publiknya jika menjadi seorang pemimpin(Van Krieken, R., Habibis, D., Hutchins, B., Martin, G. and Maton, n.d.). Perempuan lebih cenderung menghabiskan banyak dari waktu mereka untuk menyelesaikan urusan rumah tangga, hal ini berbanding terbalik dengan pihak laki-laki yang pada dasarnya lebih mempunyai tanggung jawab besar di pekerjaan daripada urusan yang ada di rumah tangga.

Perempuan juga biasanya lebih cenderung mengutamakan urusan rumah tangganya daripada urusan pekerjaan yang terksesan lebih dikesampingkan, belum lagi apabila seorang perempuan berbicara tentang kebutuhan dan urusan anak yang harus mereka penuhi terlebih dahulu daripada harus mengutamakan urusan pekerjaan. Faktorfaktor seperti inilah yang sebenarnya secara tidak langsung menggambarkan bahwa keprofesionalitasan seorang perempuan itu jauh lebih rendah daripada keprofesionalitasan seorang laki-laki dalam mengemban amanah dan tanggung jawab pekerjaan.

Untuk menjadi seorang pemimpin, seorang perempuan akan menghadapi tantangan yang lebih besar daripada tantangan yang harus dihadapi seorang laki-laki. Fleksibilitas waktu juga menjadi salah satu tantangan yang berarti bagi seorang perempuan untuk menjadi seorang pemimpin apalagi menjadi perwakilan sebuah negara di dunia internasional. Di Australia terdapat beberapa pekerjaan yang tidak diperuntukkan kepada seorang perempuan karna perempuan dianggap tidak memiliki waktu yang lebih fleksibel apabila dibandingkan dengan laki-laki, lagi lagi hal ini masih bersangkutan dengan tanggung jawab yang besar di urusan rumah tangga yang harus diemban oleh seorang perempuan. 
Apalagi jika kita berbicara tentang urusan luar negeri suatu negara tak terkecuali Australia, untuk menjadi seorang perwakilan negara seorang diplomat haruslah selalu bersedia untuk melaksanakan tugas walaupun pekerjaan tersebut sudah diluar jam kerja yang seharusnya. Melihat pertimbangan ini, pemimpin yang berasal dari gender laki-laki lebih bisa mengatasi apabila terdapat tugas-tugas tambahan seperti ini sedangkan perempuan masih terikat dengan tanggung jawab mereka dengan urusan rumah tangga. Tantangan yang juga menjadi salah satu faktor mengapa perempuan sangat jarang dipercayai menjadi seorang pemimpin karna mempertimbangkan keselamatan perempuan dalam mengurusi urusan luar negeri negara juga karna timbul keraguan bahwa perempuan belum dapat melakukan negosiasi dan mencapai kepentingan negara dengan baik malah cenderung mengabaikan dan berpotensi merusak hubungan satu negara dengan negara lain(Dee, M., 2007).

Fakta bahwa banyak pengalaman pemimpin perempuan yang berasal dari Australia mengalami diskriminasi gender sepanjang perjalanan karir mereka. Terdapat pula pernyataan yang menurut penulis adalah sebuah bukti nyata bahwa diskriminasi terhadap gender ini masih nyata adanya. Argument yang lumayan populer berasal dari Eropa menyebutkan bahwa seorang diplomat perempuan akan dilecehkan dan tidak dihargai oleh pihak asing(McCarthy, 2014). Beberapa faktor yang telah saya sebutkan diatas adalah beberapa faktor yang menjadi tantangan dan hambatan kepemimpinan seorang perempuan di berbagai negara khususnya di Australia terutama pada keterlibatan perempuan di forumforum internasional sebagai wakil dari sebuah negara. Konstruk sosial yang masih sangat memegang teguh budaya patriarki menjadi salah satu faktor terkuat mengapa perempuan selalu dianggap gender kedua dan masih dianggap sebelah mata terlepas dari kapabilitas yang dimiliki tetapi perempuan lebih cenderung telah diremehkan terlebih dahulu bahkan jauh sebelum mereka bisa membuktikannya. Hal ini terbukti bahwa keberhasilan pemimpin-pemimpin perempuan di masa lampau tidak mendapatkan perhatian yang baik dari pihak pemerintah dan masyarakat malah terkesan diabaikan, padahal seharusnya keberhasilan yang telah diperoleh oleh pemimpin-pemimpin perempuan ini dapat dijadikan contoh dan solusi bagaimana perempuan tidak lagi mengalami diskriminasi saat mereka menjalankan sebuah pekerjaan.

Penulis akan lebih memfokuskan pada kasus kepemimpinan Julia Gillard, seorang perempuan pertama yang menjadi Perdana Menteri Australia. Julia Eileen Gillard menjabat sebagai Perdana Menteri Australia pada 24 Juni 2010 sampai 27 Juni 2013. Gillard 
merupakan anggota Partai Buruh Australia dan memulai karier politiknya dari partai ini. Dalam karier politiknya, menjadi seorang Perdana Menteri ialah sebuah jabatan yang paling tinggi selama Julia Gillard menjalankan karier politiknya.

Saat menjabat sebagai seorang Perdana Menteri, Julia Gillard mengemban banyak sekali tanggung jawab dalam upaya penyelesaian masalah imigran di Australia karna mengingat meningkatnya pengungsi yang datang ke Australia sehingga membuat pihak Australia harus memutuskan suatu kebijakan yang paling tepat dalam merespon isu pencari suaka ini. Sebagai seorang yang menjabat sebagai Perdana Menteri, Julia Gillard memutuskan untuk membuka kembali pusat pemrosesan regional, hal ini dilakukan Gillard untuk dijadikan sebagai ancaman agar wilayah territorial Australia terjaga dari pencari suaka illegal yang semakin hari semakin menunjukkan angka kenaikan. Adanya pusat pemrosesan regional ini juga dicanangkan menjadi sebuah wadah proses penerimaan setiap pencari suaka yang datang secara illegal ke wilayah Australia. Hal ini diterapkan secara tegas agar memberikan efek jera kepada setiap calon pencari suaka yang akan datang ke wilayah Australia secara illegal. Bahkan dalam pidatonya, Julia Gillard mengatakan bahwa semua pengungsi yang memasuki wilayah teritori Australia menggunakan perahu dan masuk melalui jalur laut dapat dikategorikan sebagai pelanggaran hukum dan ditegaskan pula bahwa hal tersebut adalah tindakan yang illegal, Gillard juga menyampaikan bahwa pengungsi yang menggunakan perahu ini dapat dikategorikan sebagai kegiatan perdagangan manusia (Rifqi Herdianzah, 2010).

Namun sangat disayangkan, kebijakan-kebijakan yang telah dipilih oleh Julia Gillard dalam upaya menangani permasalahan pencari suaka di Australia tidak memperlihatkan hasil yang baik. Julia Gillard dinilai gagal dalam menangani permasalahan sehingga berpengaruh pada turunnya kredibilitas dan citra Julia Gillard di mata masyarakat Australia dan dunia internasional. Tidak sampai disitu saja, hal ini juga berpengaruh pada pandangan masyarakat domestik Australia dalam melihat Partai Buruh. Terlihat pada pemilihan umum selanjutnya, Partai Buruh Australia mengalami penurunan kepercayaan dari masyarakat Australia, hal ini dikarenakan isu penanganan pencari suaka di domestic Australia menjadi sebuah permasalahan yang dianggap cukup serius(R.Aj Rizka Fiani Prabaningtyas, 2015).

Kembali membahas bagaimana perempuan masih mengalami banyak diskriminasi saat menjabat sebagai seorang pemimpin, hal ini juga terjadi pada kepemimpinan Julia 
Gillard. Dimana kehidupan pribadinya menjadi sorotan penting bagi masyarakat Australia dalam upaya menjatuhkan karier politiknya. Disebutkan bahwa Julia Gillard tidak pernah menikah dan tidak mempunyai anak sehingga hal ini menjadi salah satu senjata musuh politik Julia Gillard dalam upaya menjatuhkan Gillard di kontestasi-kontestasi politik yang Gillard ikuti. Kembali muncul konstruk sosial yang membenarkan bahwa apabila perempuan menjadi seorang pemimpin maka akan ada beberapa aspek yang menjadi terabaikan seperti urusan rumah tangganya. Hal ini kembali menjadi pembenaran saat melihat seorang Julia Gillard perempuan pertama yang mampu mencapai karier politik yang tinggi yaitu menjadi seorang Perdana Menteri Australia adalah seorang perempuan yang tidak menikah dan tidak memiliki anak sehingga dalam kasus ini secara tidak langsung dibenarkan bahwa beban ganda yang diemban perempuan sejak mereka lahir adalah benar adanya.

Beban ganda yang seharusnya ditanggung oleh Julia Gillard sebagai orang yang dilahirkan menjadi seorang perempuan terkesan diabaikan akibat Julia Gillard tidak memiliki tanggung jawab untuk mengurusi urusan rumah tangganya sehingga Julia Gillard dapat mencapai karier politik yang tinggi. Rasionalitas semacam ini yang kemudian membentuk konstruk sosial di masyarakat Australia bahwa apabila seorang perempuan ingin mencapai karier politik yang tinggi maka dia harus mengabaikan salah satu beban ganda yang ia emban sejak lahir ke bumi.

Isu-isu gender semacam ini masih sangat laris dan hangat di kalangan masyarakat Australia sehingga menempatkan perempuan masih berstatus dibawah laki-laki pada sektor politik. Jika laki-laki mencalonkan diri dalam pemilihan umum maka yang menjadi perhatian ialah kapabilitasnya dalam mengemban amanah yang akan datang namun lain hal nya jika perempuan yang maju mencalonkan diri pada pemilihan umum, bukan hanya prestasi dan kapabilitasnya yang dilihat namun semua aspek terkait dapat menjadi penilaian dan menghadirkan keraguan bahwa seorang perempuan dapat berkarier dan bertugas seperti laki-laki. Anggapan bahwa kepemimpinan yang dilaksanakan oleh lakilaki selalu menghasilkan output yang lebih baik daripada masa kepemimpinan yang dilaksanakan oleh perempuan masih menjadi momok yang mengerikan untuk karier politik perempuan baik di Australia maupun di negara belahan dunia yang lain.

Budaya patriarki yang sangat mengakar di dunia ini menjadi faktor mengapa perempuan selalu dikesampingkan. Kemampuan dan bakat yang hebat namun jika hal itu 
datangnya dari seorang perempuan akan sangat sering tidak mendapatkan penilaian berarti di mata masyarakat. Lain hal nya jika kemampuan dan bakat yang hebat dan datang dari laki-laki maka hal ini menjadi sebuah penilaian yang sangat berarti apalagi jika dalam kontestasi politik. Pada umumnya seluruh perempuan di dunia yang memiliki kesadaran untuk mengambil porsi di kursi-kursi pemerintahan sering sekali dihadapkan dengan kenyataan-kenyataan dan penilaian-penilaian yang mendiskriminasi dan terkesan meragukan semua bakat dan kemampuan yang ada pada diri perempuan-perempuan calon pemimpin ini.

Angka diskriminasi terhadap perempuan menjadi tantangan sendiri bagi perempuan-perempuan calon pemimpin. Kompleksitas yang terjadi pada kepemimpinan perempuan di Australia sedikit banyak juga berasal dari masih tingginya diskriminasi yang ditujukan kepada perempuan, selain itu kegagalan-kegagalan yang terjadi pada masa kepemimpinan seorang perempuan juga seakan menguatkan alasan mengapa perempuan masih sangat diragukan untuk mengemban posisi sebagai seorang pemimpin apalagi membawahi laki-laki.

\section{KESIMPULAN}

Kompleksitas kepemimpinan perempuan di Australia dapat kita lihat dari berbagai faktor. Berdasarkan pembahasan diatas, faktor-faktor yang menjadi tantangan seorang perempuan untuk menjadi seorang pemimpin ialah masih kentalnya budaya patriartki yang ada di Australia bahkan di dunia internasional, adanya beban ganda yang dipikul perempuan sehingga membuat perempuan dianggap tidak lebih baik dari laki-laki dalam menentukan prioritas dalam bertugas, faktor selanjutnya ialah berasal dari sifat alamiah seorang perempuan yang ditakutkan akan mempengaruhi perempuan dalam menentukan sikap dan mengambil keputusan dan faktor yang terakhir ialah bukti-bukti kegagalan dari beberapa tokoh pemimpin perempuan dalam melaksanakan tugasnya, sebut saja salah satunya ialah Julia Gillard.

Jika kita telaah lebih dalam melalui kacamata politik, seperti yang kita ketahui bahwa kekuasaan akan dicapai dengan cara apapun. Maka kembali mengingatkan bahwa perempuan adalah gender kedua, masih menjadi senjata yang ampuh digunakan oleh musuh-musuh perempuan dalam kontestasi politik. Seakan-akan tidak ada kesempatan bagi 
perempuan untuk menunjukkan kemampuan dan kapabilitas mereka untuk menjadi seorang pemimpin. Perempuan sudah lebih dulu dilihat sebelah mata sebelum mereka sempat memperlihatkan kelebihan yang mereka miliki. Tantangan-tantangan seperti inilah yang akhirnya menyebabkan banyak dari perempuan mundur dari kursi jabatannya, tekanan yang sangat amat sering dilontarkan bahkan tidak jarang direndahkan menjadi pertimbangan matang mengapa banyak perempuan akhirnya tidak berani mengambil resiko untuk menjabat pada posisi-posisi penting di suatu negara.

Seperti hal nya yang terjadi di Australia, walaupun Australia menyatakan bahwa mereka memiliki Undang-Undang anti diskriminasi gender tetapi tidak bisa kita hiraukan bahwa masih banyak masyarakat Australia yang menganggap bahwa laki-laki lebih pantas menjadi seorang pemimpin daripada perempuan. Sehingga kepemimpinan perempuan di Australia masih sangat jarang diakui dengan baik, malah terkesan yang selalu diperlihatkan ialah kegagalan-kegagalan yang telah dilakukan oleh pemimpin-pemimpin perempuan terdahulu di Australia, hal ini seakan-akan dijadikan seperti standar bahwa semua perempuan yang menjabat sebagai pemimpin di Australia akan memberikan kegagalankegagalan selanjutnya di masa mendatang.

\section{DAFTAR PUSTAKA}

Burchill, S. (n.d.). Theories of International Relations.

Conley Tyler, M., E. Blizzard, and B. C. (2014). Is International Affairs Too 'Hard' for Women? Explaining the Missing Women in Australia's International Affairs. Australian Journal of International Affairs, 2, 156-176.

Danspeckgruber, W. (2010). Reflections on Women Leaders in International Relations. Women Leaders in International Relations and World Peace, 3-6.

Dee, M., and F. V. (2007). Women with a Mission: Personal Perspectives. Brown Prior Anderson.

Elise Stephenson. (2019). Domestic challenges and international leadership: a case study of women in Australian international affairs. Australian Journal of International Affairs.

Enloe, C. (2014). Bananas, Beaches and Bases: Making Feminist Sense of International Politics. University of California Press.

McCarthy, H. (2014). Women of the World: The Rise of the Female Diplomat. Bloomsbury Publishing. 
Nuranisa, E., \& Saepudin, A. (2019). Buletin Ekonomi KERJASAMA “ KEMITRAAN INDONESIA - AUSTRALIA UNTUK KESETARAAN GENDER DAN PEMBERDAYAAN PEREMPUAN " ( MAMPU ) DALAM MENGATASI PERMASALAHAN PEREMPUAN PENDAHULUAN. 1.

R.Aj Rizka Fiani Prabaningtyas. (2015). THE IMPACT OF AUSTRALIAN POLICY ON ILLEGAL MARITIME ARRIVALS (IMA) TOWARDS CURRENT RELATION OF AUSTRALIA-INDONESIA. Jurnal Penelitian Politik Volume 12 No. 1 Juni 2015, 12 No.1.

Rifqi Herdianzah, M. (2010). Kebijakan Pemerintah Australia Terkait Permasalahan Irregular Maritime Arrivals Periode Kepemimpinan Perdana Menteri Julia. www.unhcr.or.id,

Schultz, J. (2014). Theorising Australia-Pacific island relations. Australian Journal of International Affairs, 68(5), 548-568. https://doi.org/10.1080/10357718.2014.917271

Towns, A., and B. N. (2017). "Gender, International Status, and Ambassador Appointments." 521-540.

Van Krieken, R., Habibis, D., Hutchins, B., Martin, G. and Maton, K. (n.d.). Sociology: Themes and Perspectives. In 2010. pearson. 